\title{
A green and facile approach for the synthesis of silver nanoparticles using aqueous extract of Ailanthus excelsa leaves, evaluation of its antibacterial and anticancer efficacy
}

\author{
V VINMATHI and S JUSTIN PACKIA JACOB* \\ Department of Biotechnology, St. Joseph's College of Engineering, OMR, Chennai 600 119, India
}

MS received 2 December 2014; revised 13 January 2015

\begin{abstract}
Silver nanoparticles possess a wide range of applications especially in the field of medicine and this has stimulated the need for synthesizing them. Conventionally, chemical methods are used, which are hazardous and energy consuming. Therefore an eco-friendly and facile means of synthesizing nanoparticles is needed to replace the chemical method of synthesis. In the present study, silver nanoparticles were synthesized in a cost-effective and environment-friendly manner using aqueous leaf extract of Ailanthus excelsa-a medicinal tree used in the treatment of asthma, bronchitis, cold, abdominal pain, etc. The leaf extract helped in the bioreduction of silver ions yielding silver nanoparticles. The silver nanoparticles thus biosynthesized were characterized using UV-vis absorption spectroscopy, Fourier transform infrared spectroscopy (FTIR) analysis and scanning electron microscopy (SEM). These biologically synthesized silver nanoparticles were also found to exhibit excellent antibacterial effect against Staphylococcus aureus, Pseudomonas aeruginosa, Escherichia coli, Klebsiella pneumonia and anticancer effect against MCF-7 cell line.
\end{abstract}

Keywords. Silver nanoparticle; green synthesis; MTT assay; MCF-7 cell line.

\section{Introduction}

Nanotechnology is the fastest growing area of manufacturing in the world today and there is an increasingly frenetic search for new nanomaterials and methods to make them. Nanosized materials exhibit unique electronic, magnetic, optical, catalytic and medicinal properties in comparison to their counterpart bulk materials. These unique properties are due to their quantum size effect and large surface to volume ratio. ${ }^{1}$ Silver nanoparticles (AgNPs) are of great interest due to its easiness of preparation, promising physical and chemical properties and its potential applications in various fields such as oxidative catalysis, surface enhanced Raman scattering, nanoelectronics, conductive coatings, biosensors, antibacterial activity, etc. ${ }^{2}$

There are many methods for the synthesis of AgNPs such as chemical reduction, electrochemical reduction, photochemical reduction, microemulsion, $\gamma$-ray irradiation, etc. ${ }^{2}$ Most of these methods are complicated and have drawbacks like use of hazardous organic solvents, expensive reagent, toxic byproducts, drastic reaction condition and difficulty in isolation of NPs, longer time, etc. ${ }^{1}$ This has created the need to develop a green route for the synthesis of NPs such as using plant extracts or microorganisms. Synthesis of NPs using microorganisms like bacteria, fungi, yeast is an

*Author for correspondence (drjpjacob@gmail.com) elaborate, complex process involving repeated culturing, maintaining of cells and sterile conditions. Hence plant extracts are preferred instead of microorganisms for the synthesis of NPs.

Plant metabolites present in the plant extract, including terpenoids, polyphenols, sugars, alkaloids, phenolic acids and proteins, bring about bioreduction of metal ions, yielding NPs. The metal ions bind to the reducing metabolites and stabilizing agents in the plant extract and get reduced to metal atoms. The resulting complex of the metal ion and metabolite interacts with similar complexes forming a small metal NP. This is followed by growth and coalescence of individual small particles into a larger particle and this process continues until the particles assume an energetically favourable shape and size. ${ }^{3}$ Thus the plant extract acts as a reducing as well as a stabilizing agent.

AgNPs have been reported to be synthesized from various herbal plants, viz., Piper longum, ${ }^{4}$ Piper nigram, ${ }^{5}$ and Plumeria rubra, ${ }^{6}$ etc. In the present study, the leaves of Ailanthus excela were used to synthesize AgNPs. Ailanthus excela Roxb. belongs to the family of Simaroubaceae and is commonly known as Indian tree-of-heaven. For several decades it has been used in ayurvedic medicine to treat numerous disorders. The leaves are reported to possess antifertility, antifungal, antimalarial, anti-amoebic, antibacterial, hypoglycaemic, insect feedent-deterrent, antipyretic, leishmanicidal, antitumour, cytotoxicity and hepatoprotective activity. ${ }^{7}$ 


\section{Materials and methods}

\subsection{Collection of leaves}

Fresh and healthy leaves of $A$. excelsa were purchased from a local drug store in Chennai, Tamilnadu, India.

\subsection{Preparation of leaf extract}

The leaves were thoroughly washed with deionized water several times. Ten grams of leaves were chopped into pieces, homogenized and boiled in $100 \mathrm{ml}$ of distilled water for $20 \mathrm{~min}$. The mixture was allowed to cool down to room temperature and filtered with Whatman no. 1 filter paper. The filtrate was refrigerated for further experimentation.

\subsection{Synthesis of silver nanoparticles}

Briefly, $1 \mathrm{mM}$ aqueous solution of silver nitrate $\left(\mathrm{AgNO}_{3}\right)$ was prepared and used for the synthesis of AgNPs. Forty millilitres of $1 \mathrm{mM}\left(10^{-3} \mathrm{M}\right) \mathrm{AgNO}_{3}$ solution was mixed with different volumes $(1,3,5 \mathrm{ml})$ of leaf extract. This mixture solution was exposed to different physical conditions like room temperature, sunlight radiation, UV radiation and several short burst of microwave irradiation in a domestic microwave oven in a cyclic mode (on $15 \mathrm{~s}$, off $15 \mathrm{~s}$ ) to prevent overheating as well as aggregation of metals. ${ }^{8}$ The mixture solutions were maintained in these conditions until AgNPs were formed. The formation of AgNPs was manifested by the colour change.

\subsection{Instrumentation}

The colour change was due to the reduction of silver ions $\left(\mathrm{Ag}^{+}\right.$ions) to $\mathrm{AgNPs}\left(\mathrm{Ag}^{0}\right)$ which was monitored by analysing the samples using UV-vis double-beam Spectrophotometer Systronics 2201. Maximum absorbance was obtained by scanning the sample solution in the wavelength range of $200-800 \mathrm{~nm}$. Maximum absorbance $\left(\lambda_{\max }\right)$ gives the surface plasmon resonance peak, which helps us to determine the presence of silver in the solution. Fourier transform infrared (FTIR) spectroscopy analysis was carried out using Perkin Elmer Spectrum1 FTIR spectroscopy, scanned at a range $500-4000 \mathrm{~cm}^{-1}$ of resolution to determine the possible biomolecules, organic, inorganic molecules responsible for reducing silver ions to AgNPs. The other capping agents and functional groups such as $-\mathrm{OH},-\mathrm{CN}$, etc., were also identified by analysing the peaks of wave number $\left(\mathrm{cm}^{-1}\right)$. Scanning electron microscopy (SEM) analysis was carried out to determine the size and shape of the NP. The analysis was carried out in FEI QUANTA 200 FEG, FESEM at IITM, Chennai.

\subsection{Antibacterial assay}

The biosynthesized AgNPs were tested for their antibacterial efficacy by agar well diffusion method against four human pathogenic bacteria namely Staphylococcus aureus, Pseudomonas aeruginosa, Escherichia coli and Klebsiella pneumonia. Each bacterial culture was grown in nutrient broth for $24 \mathrm{~h}$. Each overnight grown culture $(100 \mu \mathrm{l})$ was spread onto a sterilized plate containing nutrient agar by the spread plate method. Wells were made on nutrient agar plates using a micropipette. Twenty microlitres of the sample of NP solution $\left(1 \mathrm{mg} \mathrm{ml}^{-1}\right)$ was poured onto wells on all plates. All the plates were incubated at $37^{\circ} \mathrm{C}$ for $24 \mathrm{~h}$. NP solution ( $1 \mathrm{mg} \mathrm{m} \mathrm{m}^{-1}$ ) was serially diluted upto 200 dilutions and the same procedure was followed. Zone of inhibition was measured on the next day.

\subsection{Cytotoxic assay (MTT assay)}

The assay was carried out at Biozone Pvt. Ltd., Chennai, India. The cytotoxicity assay of the prepared AgNP was measured using MCF-7 cell line by 3-(4,5-dimethyl thiazol-2yl)2,5-diphenyl tetrazolium bromide (MTT) test. ${ }^{9}$ Cells were maintained in DMEM medium, supplemented with $10 \%$ fetal bovine serum, at $37^{\circ} \mathrm{C}$ in humidified atmosphere with $5 \%$ $\mathrm{CO}_{2}$. The cells were plated in 96-well flat bottom tissue culture plates at a density of approximately $1.2 \times 10^{4}$ cells per well and allowed to attach overnight at $37^{\circ} \mathrm{C}$. The medium was then discarded and cells were incubated with different

Table 1. Yield of AgNPs obtained at different conditions and concentrations.

\begin{tabular}{lccc}
\hline Conditions & $\begin{array}{c}\text { Volume } \\
\text { of leaf } \\
\text { extract }(\mathrm{ml})\end{array}$ & $\begin{array}{c}\text { Time taken } \\
\text { for colour } \\
\text { change }\end{array}$ & $\begin{array}{c}\text { Yield } \\
\left(\mathrm{mg} 100 \mathrm{ml}^{-1}\right)\end{array}$ \\
\hline Sunlight & 1 & $5 \mathrm{~min}$ & 32 \\
Sunlight & 3 & $3 \mathrm{~min}$ & 39 \\
Sunlight & 5 & $3 \mathrm{~min}$ & 35 \\
Room temperature & 1 & $3 \mathrm{~h}$ & 30 \\
Room temperature & 3 & $1 \mathrm{~h}$ & 47 \\
Room temperature & 5 & $1 \mathrm{~h}$ & 43 \\
Microwave & 1 & $60 \mathrm{~s}$ & 15 \\
Microwave & 3 & $60 \mathrm{~s}$ & 20 \\
Microwave & 5 & $45 \mathrm{~s}$ & 20 \\
\hline
\end{tabular}

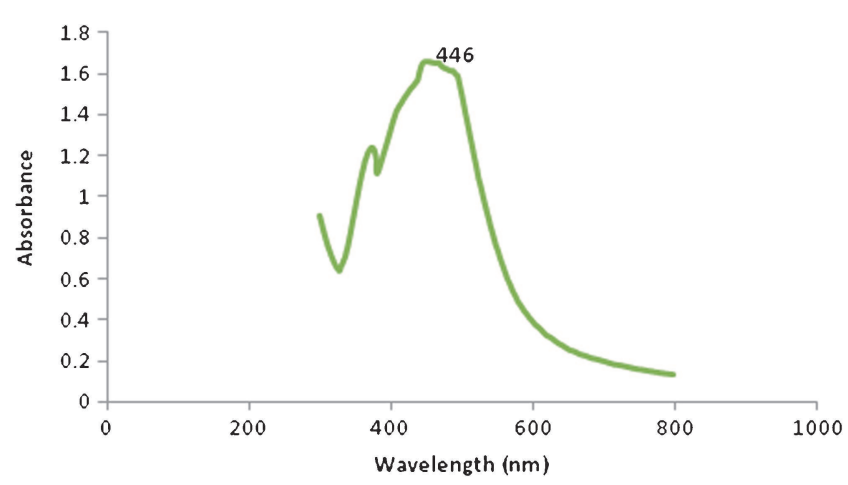

Figure 1. UV-vis spectra of the AgNPs synthesized using leaf extract of Ailanthus excelsa. 
concentrations of the extract for $24 \mathrm{~h}$. After the incubation, medium was discarded and $100 \mu \mathrm{l}$ fresh medium was added with $10 \mu \mathrm{l}$ of MTT $\left(5 \mathrm{mg} \mathrm{ml}^{-1}\right)$. After $4 \mathrm{~h}$, the medium was discarded and $100 \mu \mathrm{l}$ of DMSO was added to dissolve the formazan crystals. Then, the absorbance was read at $570 \mathrm{~nm}$ in a microtitre plate reader. The assay was performed for all 10 fractions obtained from column chromatography.

The viability was calculated by the following formula:

Cell viability $(\%)=$ Mean OD/control OD $\times 100$,

Cytotoxicity $\%=100-$ cell viability $\%$.

\section{Results and discussions}

\subsection{Formation of AgNPs}

The solution mixture containing $\mathrm{AgNO}_{3}$ solution and plant extract changed their colour from transparent yellow to dark brown when exposed to the aforementioned conditions and the colour remained unchanged for several days. The appearance of dark brown colour confirms the formation of AgNPs. ${ }^{10}$ Biosynthesized NPs were harvested and weighed to determine the yield (table 1 ). The reaction mixture containing $3 \mathrm{ml}$ of plant extract and maintained at room temperature showed maximum yield.

\section{$3.2 U$-vis spectroscopy}

The UV-vis spectroscopy analysis was performed to confirm the presence of AgNPs. The appearance of dark brownish colour was due to the excitations of surface plasmon vibrations. Maximum absorbance $\left(\lambda_{\max }\right)$ value for the NP solution was observed at $446 \mathrm{~nm}$ (figure 1). Absorption bands in the range of 425-475 correspond to spherical AgNPs of fine nature ${ }^{11}$ thus proving the biosynthesized particles are AgNPs.

\subsection{FTIR spectroscopy analysis}

FTIR absorption spectra of AgNPs produced by A. excelsa leaf extract are shown in figure 3 , bands were observed at $3450,2920,2360,1640,1380,1020$ and $669 \mathrm{~cm}^{-1}$. The above bands were compared with the FTIR spectra of $\mathrm{AgNO}_{3}$ and extract alone. The bands at 3450 and $2920 \mathrm{~cm}^{-1}$ are broadened in the extract alone, but the narrow band in the AgNPs showed that reduction of silver ions in NPs (figure 2). The band at $1620 \mathrm{~cm}^{-1}$ showed the $\mathrm{N}-\mathrm{H}$ bounding vibrate of amides indicated the presence of amides from the plant extract in the reduction of AgNPs. The shift of the band in leaf extract at $1640-1380 \mathrm{~cm}^{-1}$ after the bioreduction of

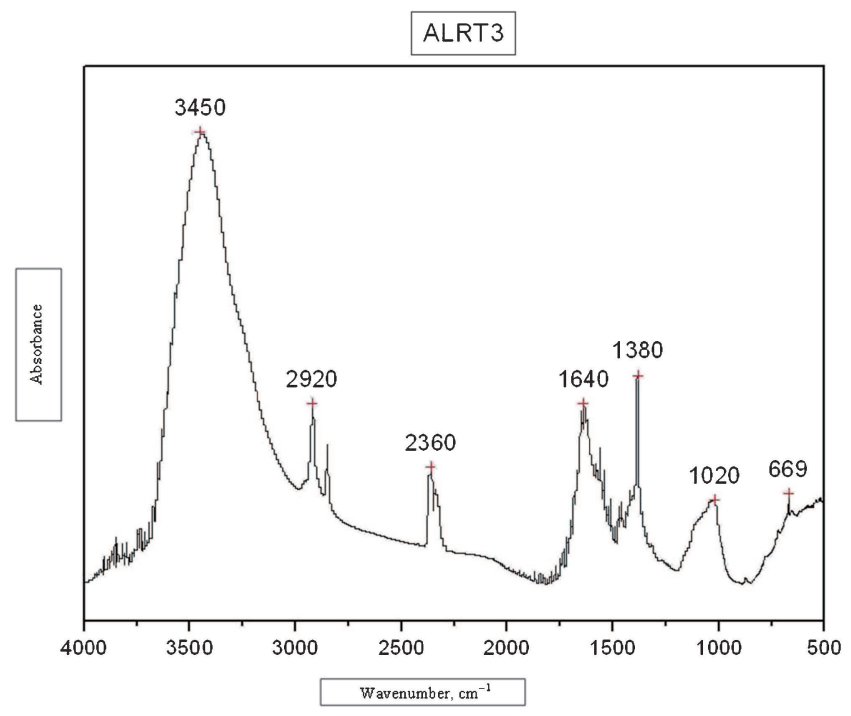

Figure 2. FTIR spectrum of the AgNPs synthesized using leaf extract of Ailanthus excelsa.
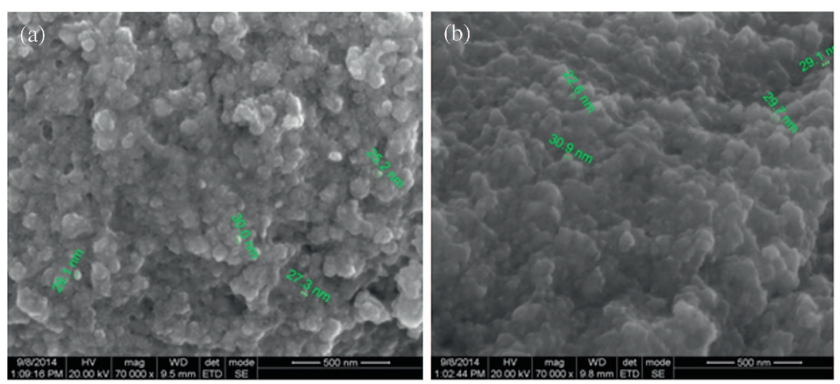

Figure 3. (a and b) SEM image of biosynthesized AgNPs using leaf extract of Ailanthus excelsa.
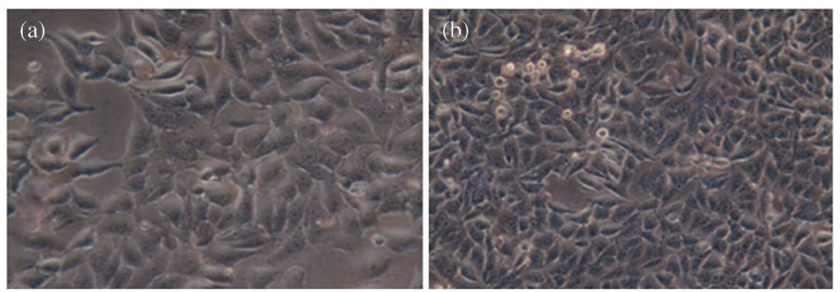

Figure 4. (a) MCF-7 cell line and (b) control. After treated with AgNPs.

Table 2. Measurement of zone of inhibition obtained at different dilutions of AgNPs.

\begin{tabular}{llccc}
\hline S. no. & Microorganism & $\begin{array}{c}\text { Zone of inhibition at } \\
\mathrm{mg} \mathrm{ml}^{-1} \text { dilution }(\mathrm{mm})\end{array}$ & $\begin{array}{c}\text { Zone of inhibition } \\
\text { at dilution } 1: 9(\mathrm{~mm})\end{array}$ & $\begin{array}{c}\text { Zone of inhibition } \\
\text { at dilution } 1: 99(\mathrm{~mm})\end{array}$ \\
\hline 1 & Escherichia coli & 6 & 6 & 4 \\
2 & Klebsiella pneumonia & 6 & 6 & - \\
3 & Staphylococcus aureus & 5 & 5 & 4 \\
4 & Pseudomonas aeruginosa & 8 & 7 & 4 \\
\hline
\end{tabular}


Table 3. Cytotoxic effect of A. exclesa-mediated AgNPs on MCF-7 cell line.

\begin{tabular}{rccccccc}
\hline $\begin{array}{l}\text { Concentration } \\
\left(\mu \mathrm{g} \mathrm{m}^{-1}\right)\end{array}$ & $\begin{array}{c}A \text { at } \\
570 \mathrm{~nm}\end{array}$ & $\begin{array}{c}A \text { at } \\
570 \mathrm{~nm}\end{array}$ & Average & SD & $\begin{array}{c}\% \text { Of } \\
\text { viability }\end{array}$ & $\begin{array}{c}\% \text { Of } \\
\text { toxicity }\end{array}$ & $\begin{array}{c}\text { IC50 } \\
\text { value }\end{array}$ \\
\hline 50 & 1.489 & 1.489 & 1.489 & 0 & 84.07 & 15.92 & 265.579 \\
100 & 1.46 & 1.459 & 1.4595 & 0.000707 & 82.41 & 17.58 & \\
150 & 1.431 & 1.433 & 1.432 & 0.001414 & 80.85 & 19.14 \\
\hline
\end{tabular}

AgNPs indicated the $\mathrm{C}=\mathrm{C}$ stretching mode in the aromatic compounds which confirmed the aromatic compounds like flavanoids in the plant extract are responsible for the reduction of AgNPs. In the earlier study, Kumar et $a l^{7}$ reported the presence of highly oxygenated and degraded triterpenes called quassinoids in Ailanthus, this may be responsible for the reduction of AgNPs.

\subsection{SEM}

The biosynthesized AgNPs were further confirmed by the structural view under the SEM. SEM analysis revealed uniformly sized and spherical shaped NPs. The size of the particles were ranging from 22 to $30 \mathrm{~nm}$ diameter (figure $3 \mathrm{a}$ and $\mathrm{b}$ ).

\subsection{Antibacterial assay}

Clear zone of inhibition on the agar plates proves the antibacterial activity of the biosynthesized NPs. In Gram-positive bacteria the action of AgNPs was very less as compared with Gram-negative bacteria (table 2). This variation was due to the differences of cell wall composition of Gram-positive and Gram-negative bacteria. The cell wall of Gram-positive bacteria is made up of thick peptidoglycan layer so the NPs did not penetrate easily. However in case of Gram-negative bacteria NPs easily penetrated and affected the permeability of the membrane due to the presence of thin layer of peptidoglycan. ${ }^{12}$

\subsection{Cytotoxic assay}

The plant extract-mediated AgNPs was tested for its cytotoxic effect using MTT on MCF-7 cell line (figure 4a). Biosynthesized AgNPs of varying concentration in cell lines were tested after $24 \mathrm{~h}$ of incubation at $37^{\circ} \mathrm{C}$ in $5 \% \mathrm{CO}_{2}$. The AgNPs brought about morphological changes in the cell line (figure 4b) and also a significant cytotoxic effect of IC50 was observed at $265.57 \mu \mathrm{g}$ of AgNPs (table 3). IC50 is the quantitative measure that indicates how much of a particular drug or other substance is needed to inhibit a given biological process by half. In the previous study quassinoids like ailanthione, glaucarubinone and a mixture of glaucarubol 15-isovalerate present in the plant extract have shown substantial antitumour and cytotoxic activities against the P388 lymphocytic leukaemia and KB test system, respectively. The observed antitumour activity is by inhibiting the protein synthesis of ribosomal peptidyl transferase leading to the termination of chain elongation. ${ }^{13}$

\section{Conclusion}

In conclusion plant-mediated synthesis of AgNPs is simple, rapid and ecofriendly. AgNPs biosynthesized using $A$. excelsa leaves were characterized using SEM, UV-vis and FTIR spectroscopic techniques. The SEM result indicated the presence of uniformly sized spherical NPs and its size ranged between 22 and $30 \mathrm{~nm}$. The reduction of silver ions and stabilization of the AgNPs was due to the participation of plant metabolites. FTIR result showed that quassinoids were responsible for the bioreduction of silver ions. Quassinoids are a group of chemical compounds that confer antimalarial, antibacterial, antitumour properties to the plant. Hence, it can be inferred that the antimicrobial and cytotoxic activity of the biosynthesized NPs is also due to the quassinoids present in the leaf extract. The cytotoxic assay confirms that the AgNPs formed by A. excelsa leaf extract exhibited excellent anticancer activity against MCF-7 cell line. Due to these properties, the biosynthesized NPs prove to be a potential candidate for medical applications. And also it can be used as an effective anticancer agent after a thorough study on animal model.

\section{References}

1. Devi H S and Singh T D 2014 Adv. Electron. Electr. Eng. 483

2. Rao Y N, Banerjee D, Datta A, Das S K, Guin R and Saha A 2010 Radiat. Phys. Chem. 791240

3. Makarov V V, Love A J, Sinitsyna O V, Makarova S S, Yaminsky I V, Taliansky M E and Kalinina N O 2014 Acta Naturae 620

4. Justin Packia Jacob S, Finub J S and Anand Narayanan P R 2012 Colloids Surf. B: Biointerfaces 91212

5. Justin Packia Jacob S, Anand Narayanan P R and Finub J S 2013 World J. Pharm. Res. 21607

6. Haseeb H S and Justin Packia Jacob S 2014 World J. Pharm. Res. 3792

7. Kumar D, Bhat Z A, Singh P, Shah M Y and Bhujbal S S 2010 Int. J. Pharmacol. 6535

8. Jancy Mary E and Inbathamizh L 2012 Asian J. Pharma. Clin. Res. 50974

9. Mossman T 1983 J. Immunol. Methods 6555

10. Singh A and Jain D 2010 Digest J. Nanomater. Biostruct. 5483

11. Shameli K, Bin Ahmad M, Jaffar Al-Mulla E A, Ibrahim N A, Shabanzadeh P, Rustaiyan A, Abdollahi Y, Bagheri S, Abdolmohammadi S, Sani Usman M and Zidan M 2012 Molecules 178506

12. Anuj S A and Bishnava K 2013 Int. J. Pharma BioSci. 4849

13. Lavhale M S and Mishra S H 2007 Pharmacognosy Rev. 1105 